\title{
NOWA GENERACJA EUROKODÓW - ZMIANY W PROJEKTOWANIU GEOTECHNICZNYM
}

\author{
Witold Bogusz $^{1 凶}$, Bolesław Kłosiński² \\ ${ }^{1}$ Instytut Techniki Budowlanej, Warszawa \\ ${ }^{2}$ Instytut Badawczy Dróg i Mostów, Warszawa
}

\begin{abstract}
STRESZCZENIE
Po kilkuletnim okresie stosowania Eurokodów, jako zharmonizowanych norm europejskich zastępujących wcześniejsze normy krajowe, oraz kilkunastu latach od ich pierwszej publikacji w obecnej formie, trwają prace nad ich kolejną generacją. Artykuł ma na celu przedstawienie stanu działań normalizacyjnych nad nową wersją Eurokodu 7, ze szczególnym uwzględnieniem jego nowej pierwszej części poświęconej wyłącznie zasadom ogólnym projektowania geotechnicznego. W celu pełnego wyjaśnienia problematyki normalizacji przedstawiono istotne kwestie powiązane $\mathrm{z}$ wewnętrznymi regulacjami CEN. Zrozumienie trudności w procesie wdrażania norm europejskich wymaga rozpatrzenia kontekstu, z którego wynikają zapisy oraz wymagania przedstawione w tych normach.
\end{abstract}

Słowa kluczowe: Eurokod 7, projektowanie geotechniczne, normalizacja

\section{WSTĘP}

Eurokody formalnie zastąpiły wcześniejsze polskie normy dopiero w 2010 roku, choć ich historia jest znacznie dłuższa i jej początki sięgają 1975 roku (Kłosiński 2017a, 2017b). Ich stosowanie szybko upowszechniło się w krajach Unii Europejskiej oraz zyskały one sporo uznania poza nią. Rozwój branży budowlanej i postęp wiedzy technicznej wymuszają regularną rewizję i aktualizację tych norm. Proces wdrażania Eurokodów ujawnił wiele braków, często wymagających uzupełnień na szczeblu krajowym lub utrudniających łatwe ich stosowanie. Z tych względów, zgodnie z mandatem M/515 Komisji Europejskiej, rozpoczęto prace nad drugą generacją Eurokodów, których głównymi celami są ulepszenie norm istniejących oraz rozszerzenie ich zakresu przez:

- opracowanie nowych norm lub nowych części obecnych norm,
- włączenie nowych wymagań użytkowych i metod projektowania,

- uczynienie obecnych norm bardziej przyjaznymi dla użytkowników,

- zwiększenie spójności między Eurokodami,

- nakierowanie na potrzeby odbiorców,

- uwzględnienie w Eurokodach wpływu prognozowanych zmian klimatu.

Artykuł przedstawia stan zaawansowania prac nad nową generacją Eurokodów w odniesieniu do projektowania geotechnicznego na koniec stycznia 2018 roku.

\section{PROCES EWOLUCJI EUROKODÓW}

Aktualizacja tak obszernego zestawu norm, jakim są Eurokody, jest znacznym wyzwaniem dla podległego CEN komitetu TC250 „Structural design” i krajowych instytucji normalizacyjnych. $Z$ uwagi na skomplikowanie tego procesu oraz zaangażowanie

${ }^{\bowtie}$ w.bogusz@itb.pl 
znacznej liczby ekspertów, przy jednoczesnej konieczności poszanowania regulacji krajowych, wymaga to działania w zakresie odgórnie narzuconych reguł i wielu ograniczeń.

\section{Wytyczne i założenia}

W celu zachowania spójności wymagań między poszczególnymi normami oraz zgodności $\mathrm{z}$ wewnętrznymi regulacjami CEN (CEN-CENELEC, 2017) opracowano poradnik CEN/TC250 N1250 (2017) stanowiący zbiór wytycznych do stworzenia nowych norm narzucających ograniczenia w kwestii ich zakresu.

W pierwszej kolejności należy zauważyć, że przyjmowany jest jasny rozdział między wymaganiami dokumentów o różnym statusie. W celu zapewnienia właściwego poziomu niezawodności, w przypadku występowania niespójnych wymagań, obowiązuje następująca kolejność wagi dokumentów odniesienia: ustawy i rozporządzenia, normy europejskie, normy krajowe, wymagania i specyfikacje inwestora. W praktyce oznacza to, że w miarę możliwości już na etapie opracowywania norm należy unikać możliwych konfliktów z dokumentami nadrzędnymi wynikającymi z ustawodawstwa krajów członkowskich CEN. Jednocześnie na poziomie krajowym powinno dążyć się do dostosowania przepisów krajowych, tak aby były spójne ze zharmonizowanymi normami europejskimi, i powoli tak się dzieje.

Jako główną grupę docelową odbiorców nowych Eurokodów przewidziano (CEN/TC250 N1250, 2017) doświadczonych inżynierów budownictwa, konstruktorów i geotechników, których zdefiniowano jako wykwalifikowanych specjalistów mogących samodzielnie wykonywać swój zawód. Z uwagi na to, że użytkownikami norm są także inne grupy, przewidziano również uwzględnienie ich potrzeb. Do tych grup zaliczono: początkujących inżynierów, ekspertów, producentów materiałów, producentów oprogramowania, wykładowców, krajowych ustawodawców, prywatne przedsiębiorstwa, inwestorów, a także inne komitety CEN.

Ponadto normy mają na celu tylko przedstawienie zbioru wymagań i rekomendacji. Nie mogą bezpośrednio wskazywać, kto ponosi odpowiedzialność za ich wdrażanie i realizację. Ten aspekt powinien być uregulowany prawnie w kraju członkowskim lub kontraktowo w procesie inwestycyjnym. Dotyczy to również docelowego poziomu niezawodności, który nie powinien być ustalony w normie z pozbawieniem krajów członkowskich możliwości jego modyfikacji przez załącznik krajowy.

Do decyzji krajowej również pozostawiono kwestie załączników do nowych norm. Załączniki normatywne mają charakter bezwzględnie obowiązujący. Informacyjne $\mathrm{z}$ kolei przez załącznik krajowy mogą zostać zaakceptowane, odrzucone lub można im nadać status załączników normatywnych.

W obecnych pracach nad ewolucją Eurokodów zwrócono również uwagę na zapewnienie transparentności procesu normalizacji. $\mathrm{W}$ tym celu, równolegle z opracowaniem wersji roboczych norm, opracowywane i archiwizowane sa dokumenty majace na celu śledzenie wprowadzanych zmian, np. CEN/TC250/ /SC7 N1111 (2017).

\section{Stan obecny}

Pierwsza wersja robocza tekstu pierwszej części nowego Eurokodu 7, podzielonego na trzy odrębne części (Kłosiński, 2017b), została przedstawiona w połowie 2017 roku. Zgłoszono do niej 1148 uwag z całej Europy, w tym również wiele z Polski. Znaczna część tych uwag została w pełni (40\%) lub częściowo (33\%) zaakceptowana. Na ich podstawie w październiku 2017 roku została opublikowana ostateczna wersja robocza, do której zgłoszono kolejne komentarze.

\section{Kontynuacja prac}

Na kwiecień 2018 roku planowana jest publikacja już ostatecznej treści prEN 1997-1:2017 (zasady ogólne), która po zakończeniu prac nad całością Eurokodu 7 będzie podlegać już tylko nieznacznej rewizji w celu pełnej harmonizacji jej zapisów z planowaną drugą częścią (badania podłoża) oraz trzecią (konstrukcje geotechniczne). Zakończenie tych prac jest przewidywane na połowę 2021 roku. Ostateczne zakończenie prac nad nową generacją Eurokodów, łącznie $\mathrm{z}$ rewizją ich spójności, jest planowane na przełom lat 2022/2023. W 2024 roku krajowe komitety będą musiały przygotować swoje załączniki. Planowany okres użytkowania nowych norm to w przybliżeniu lata 2025-2040, po czym najprawdopodobniej nastąpi potrzeba ponownej ich aktualizacji. 


\section{EN 1990 EUROKOD 0 - PODSTAWY PROJEKTOWANIA}

Do pełnego zrozumienia założeń Eurokodu 7 nowej generacji konieczna jest znajomość zmian, jakie wprowadzano $\mathrm{w}$ zakresie podstaw projektowania przez prEN 1990:2017. Dotychczas Eurokod 0 (PN-EN 1990:2004) był najczęściej traktowany jako podstawa teoretyczna dla pozostałych Eurokodów, bez istotnej wartości praktycznej, ale wiele obecnie wprowadzonych zmian dla konkretnych rodzajów konstrukcji jest rezultatem modyfikacji normy prEN 1990:2017.

Podstawowym założeniem normy nadal pozostaje wymaganie, aby odpowiednio wykwalifikowany i doświadczony personel odpowiadał za pozyskanie i interpretacje danych, projektowanie, nadzór oraz właściwe użytkowanie i eksploatację. Z tego względu nie należy oczekiwać po nowej generacji Eurokodów rozwiązań problemów innych niż kwestie czysto techniczne. Profesjonalizm i zachowanie zdrowego rozsądku w projektowaniu i przy wykonawstwie będzie jeszcze ważniejsze niż dotychczas.

Załącznik informacyjny $\mathrm{C}$ Eurokodu 0 przedstawia różne możliwości zapewnienia niezawodności konstrukcji, które mogą być stosowane w obszarze budownictwa: podejście pół-probabilistyczne, bezpośrednia ocena niezawodności oraz podejmowanie decyzji, wykorzystując analizy ryzyka, w obliczu znacznej niepewności, potencjalnych konsekwencji czy w przypadku konieczności odstępstwa od wymagań przedstawionych w normie.

\section{Zróżnicowanie poziomu niezawodności}

Jedną z koncepcji wprowadzanych w nowej generacji Eurokodów jest zróżnicowanie poziomu niezawodności konstrukcji. Rozwiązania takie zostały już w różnej formie wprowadzone na świecie, np. w australijskiej normie do projektowania pali (AS 2159, 2009) czy kanadyjskiej normie dla fundamentów konstrukcji mostowych (S6-14, 2014). Same podstawy zapewnienia niezawodności konstrukcji można znaleźć w normie PN-ISO 2394:2015. Te istniejące już rozwiązania, jak i coraz częstsze publikacje naukowe (Poulos, 2004; Fenton, Naghibi, Dundas, Bathurst i Griffiths, 2016) stanowiły inspirację do wdrożenia systemu różnicowania poziomu niezawodności przez modyfikację współczynników częściowych oraz wymagań.

Zróżnicowanie poziomu niezawodności zdefiniowano w Eurokodzie 0 (PN-EN 1990:2004) jako mające na celu optymalizację społeczno-ekonomiczną zasobów wykorzystywanych przy realizacji prac budowlanych, z uwzględnieniem wszelkich przewidywanych konsekwencji zniszczenia oraz kosztów realizacji prac. Istotnym elementem tej koncepcji jest proponowany w załączniku informacyjnym B normy prEN 1990:2017. System zarządzania jakością. Jego najważniejsze elementy i sposób implementacji w projektowaniu geotechnicznym przedstawiono $\mathrm{w}$ dalszej części artykułu.

Wprowadzono również dalsze zróżnicowanie wymagań stosowanych dla normalnych obiektów budowlanych i obiektów o specjalnym przeznaczeniu, takich jak: wieże i kominy, silosy i zbiorniki, a także konstrukcje wsporcze żurawi i innych maszyn.

\section{Klasy konsekwencji}

Choć dotychczasowa norma PN-EN 1990:2004 wprowadzała $\mathrm{w}$ załączniku informacyjnym koncepcję trzech klas konsekwencji zniszczenia, obecny projekt normy prEN 1990:2017 kładzie jeszcze większy nacisk na ich zastosowanie. W praktyce krajowej koncepcja konsekwencji zniszczenia obowiązuje dotychczas tylko w przypadkach wybranych konstrukcji o specjalnym znaczeniu, np. hydrotechnicznych (Ministerstwo Środowiska, 2007). Rozszerzenie jej stosowania na obiekty budownictwa powszechnego może przyczynić się do lepszego zrównoważenia kwestii ekonomicznych i wymaganego poziomu niezawodności. W tabeli 1 przedstawiono podsumowanie informacji dotyczących proponowanych obecnie pięć klas konsekwencji zniszczenia. Należy zwrócić uwagę, że Eurokody nie obejmują konstrukcji o najniższej klasie, o najmniejszym znaczeniu i konsekwencjach ich zniszczenia ani takich o najwyższej klasie, bardzo dużym znaczeniu oraz konsekwencjach ich destrukcji.

Klasyfikacja konstrukcji na klasy konsekwencji zniszczenia może mieć wpływ na wartości współczynników częściowych do oddziaływań i ich efektów poprzez współczynnik konsekwencji $\left(K_{f}\right)$. 
Bogusz, W., Kłosiński, B. (2018). Nowa generacja Eurokodów - zmiany w projektowaniu geotechnicznym. Acta Sci. Pol. Architectura, 17 (2), 25-35. doi: 10.22630/ASPA.2018.17.2.12

Tabela 1. Klasy konsekwencji zniszczenia, przykłady i współczynniki - PN-EN 1990:202x - wersja robocza z października 2017 roku (zaadaptowane za Bondem 2017)

Table 1. Consequence classes, examples, and factors - PN-EN 1990:202x - October 2017 draft (adapted after Bond 2017)

\begin{tabular}{|c|c|c|c|c|c|}
\hline \multicolumn{2}{|c|}{$\begin{array}{c}\text { Klasa konsekwencji, Opis } \\
\text { Consequence class, Description }\end{array}$} & $\begin{array}{c}\text { Zagrożenie } \\
\text { życia ludzkiego } \\
\text { Loss of human life }\end{array}$ & $\begin{array}{l}\text { Konsekwencje } \\
\text { ekonomiczne, } \\
\text { społeczne, } \\
\text { środowiskowe } \\
\text { Economic, social } \\
\text { or environmental }\end{array}$ & $\begin{array}{l}\text { Przykłady budynków } \\
\text { Examples of buildings }\end{array}$ & $\begin{array}{c}\text { Współczynnik } \\
\text { Factor } \\
K_{F}\end{array}$ \\
\hline $\mathrm{CC} 4$ & $\begin{array}{l}\text { najwyższa } \\
\text { highest }\end{array}$ & $\begin{array}{l}\text { ekstremalne } \\
\text { extreme }\end{array}$ & $\begin{array}{l}\text { ogromne } \\
\text { huge }\end{array}$ & \multicolumn{2}{|c|}{$\begin{array}{l}\text { poza zakresem Eurokodów } \\
\text { outside the scope of Eurocodes }\end{array}$} \\
\hline $\mathrm{CC} 3$ & $\begin{array}{l}\text { wysoka } \\
\text { higher }\end{array}$ & $\begin{array}{l}\text { wysokie } \\
\text { high }\end{array}$ & $\begin{array}{l}\text { bardzo duże } \\
\text { very great }\end{array}$ & $\begin{array}{c}\text { obiekty monumentalne, duż } \\
\text { obiekty publiczne } \\
\text { grandstands, large public } \\
\text { buildings }\end{array}$ & 1,10 \\
\hline $\mathrm{CC} 2$ & $\begin{array}{c}\text { normalna } \\
\text { normal }\end{array}$ & $\begin{array}{l}\text { średnie } \\
\text { medium }\end{array}$ & $\begin{array}{c}\text { znaczące } \\
\text { considerable }\end{array}$ & $\begin{array}{l}\text { niewielkie budynki } \\
\text { mieszkalne i biurowe } \\
\text { residential and office } \\
\text { buildings, small buildings }\end{array}$ & 1,00 \\
\hline $\mathrm{CC} 1$ & $\begin{array}{l}\text { niska } \\
\text { lower }\end{array}$ & $\begin{array}{l}\text { niskie } \\
\text { low }\end{array}$ & $\begin{array}{l}\text { małe } \\
\text { small }\end{array}$ & $\begin{array}{c}\text { budynki rolnicze, } \\
\text { budynki nieprzeznaczone } \\
\text { na pobyt ludzi } \\
\text { agricultural buildings, } \\
\text { buildings where people } \\
\text { do not normally enter }\end{array}$ & 0,90 \\
\hline $\mathrm{CC} 0$ & $\begin{array}{c}\text { najniższa } \\
\text { lowest }\end{array}$ & $\begin{array}{l}\text { bardzo niskie } \\
\text { very low }\end{array}$ & $\begin{array}{l}\text { nieistotne } \\
\text { negligible }\end{array}$ & $\begin{array}{l}\text { poza zakresem Eur } \\
\text { outside the scope of }\end{array}$ & $\begin{array}{l}\text { kodów } \\
\text { urocodes }\end{array}$ \\
\hline
\end{tabular}

Bezpośrednim celem tego podejścia jest zwiększenie lub zmniejszenie poziomu niezawodności konstrukcji, aby rozsądnie zbalansować wymagania bezpieczeństwa z wymaganiami ekonomicznymi. Pośrednio przyczynia się ono również do rzeczywistego zastanowienia się nad potencjalnymi konsekwencjami zniszczenia projektowanej konstrukcji.

\section{Projektowany okres użytkowania}

Planowany okres użytkowania obiektu budowlanego jest powiązany $\mathrm{z}$ niezawodnością. $\mathrm{Z}$ tego względu projekt normy obejmuje również podział na kategorie okresu użytkowania obiektów budowlanych. Długość okresu w zależności od przyjętej kategorii wraz z przykładami budowli przedstawiono w tabeli 2 . Dodatkowo elementy konstrukcyjne podlegające ponownemu wykorzystaniu nie powinny być klasyfikowane jako konstrukcje tymczasowe. Przedstawione wartości mogą podlegać modyfikacji w załączniku krajowym do EC0.

\section{Stany graniczne nośności}

Najistotniejszą zmianą w zakresie weryfikacji stanów granicznych nośności jest likwidacja opisowego podziału stanów granicznych nośności jako: STR, EQU, GEO, UPL, HYD i FAT.

Druga $\mathrm{z}$ istotnych zmian, wprowadzona w prEN 1990:2017 i mająca znaczny wpływ na projektowanie geotechniczne, dotyczy oddziaływań związanych z wodą. Zasady w obecnej wersji EC7-1 są niespójne i niejasne, czego dowodzą niejednoznaczne, a niekiedy nieprawdopodobne wyniki obliczeń 
Bogusz, W., Kłosiński, B. (2018). Nowa generacja Eurokodów - zmiany w projektowaniu geotechnicznym. Acta Sci. Pol. Architectura, 17 (2), 25-35. doi: 10.22630/ASPA.2018.17.2.12

Tabela 2. Definicja kategorii okresu użytkowania dla budynków i konstrukcji geotechnicznych - prEN 1990:2017

Table 2. Definition of design working life categories for buildings and geotechnical structures - prEN 1990:2017

\begin{tabular}{ccc}
\hline $\begin{array}{c}\text { Projektowana kategoria } \\
\text { okresu użytkowania } \\
\begin{array}{c}\text { Design working life } \\
\text { category }\end{array}\end{array}$ & $\begin{array}{c}\text { Przykłady budowli } \\
\text { Examples of structures }\end{array}$ & $\begin{array}{c}\text { Projektowany okres } \\
\text { użytkowania } \\
\text { Design working life }-T_{\text {life }} \\
\text { [years] }\end{array}$ \\
\hline 4 & $\begin{array}{c}\text { budowle monumentalne, mosty, inne obiekty budownictwa lądowego } \\
\text { monumental building structures, bridges, and other civil engineering } \\
\text { structures }\end{array}$ & 100 \\
\hline 3 & $\begin{array}{c}\text { typowe obiekty budowlane niezaliczane do innych kategorii } \\
\text { building structures and other common structures not covered by another } \\
\text { category }\end{array}$ & 50 \\
\hline & $\begin{array}{c}\text { obiekty budownictwa rolniczego, przemysłowego i podobne } \\
\text { elementy konstrukcyjne mogące podlegać wymianie } \\
\text { agricultural, industrial, and similar structures } \\
\text { replaceable structural parts }\end{array}$ & 25 \\
\hline & $\begin{array}{c}\text { tymczasowe obiekty budowlane } \\
\text { temporary structures }\end{array}$ & $\leq 10$ \\
\hline
\end{tabular}

(Kłosiński, 2017c). Krytykowane jest zwłaszcza mnożenie ciśnienia wody przez współczynniki częściowe, co może prowadzić do wyników fizycznie niemożliwych. W projekcie EC0 wartości parcia wody rozdzielono na wartości stałe oraz zmienne, a także przedstawiono podstawowe zapisy dotyczące klasyfikacji oddziaływań wynikających z działania wody, w tym gruntowej. Odziaływania te można zaklasyfikować jako:

- stałe - gdy roczne prawdopodobieństwo przekroczenia wynosi $50 \%$ lub więcej;

- zmienne - gdy roczne prawdopodobieństwo przekroczenia wynosi 0,5\%, jeśli załącznik krajowy nie definiuje innej wartości - okres powrotu 200 lat;

- wyjątkowe - gdy roczne prawdopodobieństwo przekroczenia wynosi $0,14 \%$, jeśli załącznik krajowy nie definiuje innej wartości - okres powrotu 700 lat.

Podane wartości prawdopodobieństw mogą ulec zmianie w ostatecznych ustaleniach komitetu CEN/ /TC250/SC10.

W nowej wersji normy pojawił się również termin solidności (ang. robustness), którą zdefiniowano jako zdolność konstrukcji do przetrwania niekorzystnych i nieprzewidzianych zdarzeń bez wywołania uszkodzeń nieproporcjonalnie dużych w stosunku do oryginalnej przyczyny. Dotychczas tematykę tę szeroko analizował Simpson (2017).

\section{Stany graniczne użytkowalności}

W projekcie nowej normy prEN 1990:2017 zwiększono nacisk na wymagania odnośnie użytkowalności obiektów budowlanych i weryfikacji stanów granicznych $\mathrm{z}$ nią związanych. W tym celu przedstawiono propozycję klas wrażliwości, którą podsumowano w tabeli 3, oraz przykłady budynków klasyfikowanych do tych klas w tabeli 4.

Wartości te mogą podlegać dalszym zmianom przed zakończeniem prac i będą mogły być zmienione w załącznikach krajowych. Choć Eurokody nie mogą bezpośrednio przypisywać odpowiedzialności za poszczególne działania, wskazuje to na projektanta konstrukcji jako osobę odpowiedzialną za zdefiniowanie kryteriów użytkowalności w projekcie konstrukcji. W praktyce, w niektórych przypadkach (np. przyłącza instalacji na terenach górniczych, fundamenty mostów w kontakcie $\mathrm{z}$ nasypem itp.) mogą być wymagane wyższe klasy wrażliwości i propozycja z projektu normy (prEN 1990:2017) będzie wymagać uzupełnienia. 
Bogusz, W., Kłosiński, B. (2018). Nowa generacja Eurokodów - zmiany w projektowaniu geotechnicznym. Acta Sci. Pol. Architectura, 17 (2), 25-35. doi: 10.22630/ASPA.2018.17.2.12

Tabela 3. Kryteria użytkowalności dla różnych klas wrażliwości - prEN 1990:2017

Table 3. Serviceability criteria for different structural sensitivity classes - prEN 1990:2017

\begin{tabular}{|c|c|c|c|c|}
\hline \multirow{2}{*}{$\begin{array}{l}\text { Klasa wrażliwości } \\
\text { konstrukcji } \\
\text { Structural } \\
\text { sensitivity class }\end{array}$} & \multirow[b]{2}{*}{$\begin{array}{l}\text { Opis wrażliwości } \\
\text { Description } \\
\text { of sensitivity }\end{array}$} & \multicolumn{3}{|c|}{$\begin{array}{c}\text { Kryteria użytkowalności } \\
\text { Design serviceability criteria }\left(C_{d}\right)\end{array}$} \\
\hline & & $\begin{array}{l}\text { maksymalne osiadanie } \\
\text { maximum settlement } \\
\qquad\left(s_{C d}\right)\end{array}$ & $\begin{array}{c}\text { maksymalne } \\
\text { przemieszczenie kątowe } \\
\text { maximum angular } \\
\text { distortion }\left(\beta_{C d}\right)\end{array}$ & $\begin{array}{c}\text { maksymalne } \\
\text { przechylenie } \\
\text { maximum tilt }\left(\omega_{C d}\right)\end{array}$ \\
\hline SSC5 & najwyższa - the highest & $10 \mathrm{~mm}$ & $0,05 \%$ & $0,1 \%$ \\
\hline SSC4 & wysoka - higher & $15 \mathrm{~mm}$ & $0,075 \%$ & $0,2 \%$ \\
\hline SSC3 & normalna - normal & $30 \mathrm{~mm}$ & $0,15 \%$ & $0,3 \%$ \\
\hline $\mathrm{SSC} 2$ & niższa - lower & $60 \mathrm{~mm}$ & $0,3 \%$ & $0,4 \%$ \\
\hline SSC1 & najniższa - the lowest & $100 \mathrm{~mm}$ & $0,5 \%$ & $0,5 \%$ \\
\hline
\end{tabular}

Tabela 4. Przykłady budynków zaliczanych do różnych klas wrażliwości - prEN 1990:2017

Table 4. Examples of buildings in different sensitivity classes - prEN 1990:2017

\begin{tabular}{|c|c|c|}
\hline $\begin{array}{l}\text { Kryteria użytkowalności } \\
\text { Serviceability criteria }\left(C_{d}\right)\end{array}$ & $\begin{array}{l}\text { Typ obiektu } \\
\text { Type of structure }\end{array}$ & $\begin{array}{c}\text { Klasa wrażliwości konstrukcji } \\
\text { Structural sensitivity class }\end{array}$ \\
\hline \multirow{2}{*}{$\begin{array}{l}\text { Osiadanie } \\
\text { Settlement } \\
\quad\left(s_{C d}\right)\end{array}$} & $\begin{array}{l}\text { przyłącza instalacji } \\
\text { utility connections }\end{array}$ & $\mathrm{SSC} 1$ \\
\hline & $\begin{array}{l}\text { fundamenty mostów } \\
\text { bridge foundations }\end{array}$ & $\mathrm{SSC} 2$ \\
\hline \multirow{4}{*}{$\begin{array}{l}\text { Przemieszczenie kątowe } \\
\text { Angular distortion }\left(\beta_{C d}\right)\end{array}$} & $\begin{array}{l}\text { budynki o konstrukcji ramowej; zbrojone ściany } \\
\text { nośne; zbiorniki stalowe; tory podsuwnicowe } \\
\text { framed buildings; reinforced load-bearing walls; } \\
\text { steel storage tanks; crane rails }\end{array}$ & SSC3 \\
\hline & $\begin{array}{l}\text { płyty } \\
\text { floors; slabs }\end{array}$ & $\mathrm{SSC} 1$ \\
\hline & $\begin{array}{l}\text { maszyny (zakres) } \\
\text { machinery (range) }\end{array}$ & SSC2-SSC5 \\
\hline & $\begin{array}{l}\text { maszyny (typowe) } \\
\text { machinery (typical) }\end{array}$ & SSC3 \\
\hline \multirow[t]{2}{*}{$\begin{array}{l}\text { Przechylenie } \\
\text { Tilt }\left(\omega_{C d}\right)\end{array}$} & $\begin{array}{l}\text { wieże, budynki wysokie; wysokość: } \\
\text { towers, tall buildings (visual), height: } \\
\qquad \begin{array}{c}H<24 \mathrm{~m} \\
24 \mathrm{~m} \leq H<60 \mathrm{~m} \\
60 \mathrm{~m} \leq H<100 \mathrm{~m} \\
100 \mathrm{~m}<H\end{array}\end{array}$ & $\begin{array}{l}\mathrm{SSC} 2 \\
\mathrm{SSC} 3 \\
\mathrm{SSC} 4 \\
\mathrm{SSC} 5\end{array}$ \\
\hline & $\begin{array}{l}\text { działanie wind i schodów ruchomych } \\
\text { lift and escalator operations }\end{array}$ & SSC5 \\
\hline
\end{tabular}




\section{EUROKOD 7 - PROJEKTOWANIE GEOTECHNICZNE}

Wprowadzane w Eurokodzie 7 zmiany dotykają praktycznie wszystkich aspektów obecnej praktyki projektowania geotechnicznego. Podstawowym założeniem jest jednak ewolucja na bazie obecnej treści normy. Podejście to pozwala na uwzględnienie rozwiązań już sprawdzonych w praktyce, jednocześnie zwiększając szansę na pozytywny odbiór nowej normy przez branżę budowlaną. Należy jednak zauważyć, że znaczna część przedstawionych zmian wynika z konieczności zachowania spójności Eurokodu 7 (PN-EN 1997-1:2008) z wymaganiami Eurokodu 0 (PN-EN 1990:2004) przedstawionymi wcześniej i leżała poza kompetencją komitetu CEN TC250/SC7.

\section{Współczynniki częściowe}

Podstawowa zmiana związana z uproszczeniem, choć tylko częściowym, nowego Eurokodu 7 to zastąpienia podejść obliczeniowych przez tzw. przypadki obliczeniowe. Zaproponowane współczynniki częściowe do oddziaływań i ich efektów przedstawiono w tabeli 5.

Tabela 5. Współczynniki częściowe dla budynków i konstrukcji geotechnicznych - prEN 1990:2017

Table 5. Partial factors on actions for buildings and geotechnical structures - prEN 1990:2017

\begin{tabular}{|c|c|c|c|c|c|c|c|c|}
\hline \multicolumn{4}{|c|}{$\begin{array}{l}\text { Oddziaływania lub ich efekty } \\
\text { Action or effect }\end{array}$} & \multicolumn{5}{|c|}{$\begin{array}{l}\text { Współczynnik częściowy dla przypadku obliczeniowego } \\
\text { Partial factor for design cases }\left(\gamma_{F}\right)\end{array}$} \\
\hline \multirow[b]{2}{*}{$\begin{array}{l}\text { Typ } \\
\text { Type }\end{array}$} & \multirow[b]{2}{*}{$\begin{array}{l}\text { Grupa } \\
\text { Group }\end{array}$} & \multirow[b]{2}{*}{ Symbol } & \multirow{2}{*}{$\begin{array}{c}\text { Efekt } \\
\text { oddziaływa- } \\
\text { nia } \\
\text { Resulting } \\
\text { effect }\end{array}$} & DC1 & \multicolumn{2}{|c|}{ DC2 } & $\mathrm{DC} 3$ & DC4 \\
\hline & & & & $\begin{array}{l}\text { wszystkie } \\
\text { all }\end{array}$ & \multicolumn{2}{|c|}{$\begin{array}{c}\text { stateczność ogólna i wypór } \\
\text { static equilibrium and } \\
\text { uplift }\end{array}$} & \multicolumn{2}{|c|}{$\begin{array}{c}\text { projektowanie } \\
\text { geotechniczne } \\
\text { geotechnical design }\end{array}$} \\
\hline \multirow{3}{*}{$\begin{array}{l}\text { Oddziaływania } \\
\text { stałe } \\
\text { Permanent } \\
\text { action } \\
\left(G_{k}\right)\end{array}$} & $\begin{array}{c}\text { wszystkie } \\
\text { (bez wody) } \\
\text { all } \\
\text { (excl. water) }\end{array}$ & $\gamma_{G}$ & \multirow[t]{2}{*}{$\begin{array}{l}\text { niekorzystne } \\
\text { unfavourable }\end{array}$} & $1,35 K_{F}$ & $1,35 \rho K_{F}$ & 1,00 & 1,00 & \multirow{3}{*}{$\begin{array}{l}\text { niestosowane } \\
\text { not used }\end{array}$} \\
\hline & $\begin{array}{l}\text { woda } \\
\text { water pressures }\end{array}$ & $\gamma_{G, w}$ & & $1,20 K_{F}$ & $1,20 \rho K_{F}$ & 1,00 & 1,00 & \\
\hline & $\begin{array}{l}\text { wszystkie } \\
\text { all }\end{array}$ & $\gamma_{G, f a v}$ & $\begin{array}{l}\text { korzystne } \\
\text { favourable }\end{array}$ & 1,00 & 1,00 & 1,00 & 1,00 & \\
\hline \multirow{3}{*}{$\begin{array}{c}\text { Oddziaływania } \\
\text { zmienne } \\
\text { Variable action } \\
\left(Q_{k}\right)\end{array}$} & $\begin{array}{l}\text { wszystkie } \\
\text { (bez wody) } \\
\text { all } \\
\text { (excl. water) }\end{array}$ & $\gamma_{Q}$ & \multirow[t]{2}{*}{$\begin{array}{l}\text { niekorzystne } \\
\text { unfavourable }\end{array}$} & $1,50 K_{F}$ & $1,50 K_{F}$ & $1,50 K_{F}$ & 1,30 & 1,10 \\
\hline & $\begin{array}{c}\text { woda } \\
\text { water pressures }\end{array}$ & $\gamma_{Q, w}$ & & $1,20 K_{F}$ & $1,20 K_{F}$ & $1,20 K_{F}$ & 1,00 & 1,00 \\
\hline & $\begin{array}{l}\text { wszystkie } \\
\text { all }\end{array}$ & $\gamma_{Q, f a v}$ & $\begin{array}{l}\text { korzystne } \\
\text { favourable }\end{array}$ & & & 0 & & \\
\hline \multirow{2}{*}{\multicolumn{2}{|c|}{$\begin{array}{l}\text { Efekty oddziaływania } \\
\text { Action-effects } \\
(E)\end{array}$}} & $\gamma_{E}$ & $\begin{array}{l}\text { niekorzystne } \\
\text { unfavourable }\end{array}$ & \multirow{2}{*}{\multicolumn{3}{|c|}{$\begin{array}{l}\text { niestosowane } \\
\text { not used }\end{array}$}} & & $1,35 K_{F}$ \\
\hline & & $\gamma_{E f f a v}$ & $\begin{array}{l}\text { korzystne } \\
\text { favourable }\end{array}$ & & & & & 1,00 \\
\hline
\end{tabular}

$K_{F}$ - współczynnik konsekwencji; $\rho$ - współczynnik redukcyjny, wynosi 0,85 , jeśli nie wskazano inaczej w załączniku krajowym. $K_{F}-$ consequence factor; $\rho$ - reduction factor, its value is 0.85 unless otherwise specified in the National Annex. 
Projekt normy wskazuje również, które przypadki obliczeniowe mogą być stosowane w odniesieniu do konkretnych konstrukcji geotechnicznych. Przedstawiona propozycja jest również próbą adaptacji kombinacji współczynników częściowych, które były najczęściej preferowane w większości krajów. Choć nie jest ona tak przejrzysta i intuicyjna, jak można byłoby oczekiwać, stanowi niezbędny kompromis między stanowiskami przedstawicieli różnych krajów. Współczynniki częściowe do nośności zostaną przedstawione w trzeciej części normy odnoszącej się do konkretnych konstrukcji geotechnicznych.

\section{Zmiany $\mathbf{w}$ analizie stanów granicznych}

Poza zmianami, w większości kosmetycznymi, w kwestii stosowania współczynników częściowych generalnie koncepcja weryfikacji stanów granicznych nośności (SGN) nie uległa zmianie. Dotychczasowe wymagania PN-EN 1997:2004 w odniesieniu do analizy SGN z uwagi na zniszczenie hydrauliczne były bardzo ogólne i nie oferowały jasnego zestawu wymagań czy modeli obliczeniowych. Projekt nowej normy rozwija tę tematykę, choć w stopniu nadal wymagającym specjalistycznej wiedzy od projektantów.

Kolejną istotną zmianą jest wprowadzenie w tekście prEN 1997:2017 bardziej klarownych kryteriów weryfikacji stanów granicznych użytkowalności (SGU). Dotychczas sprawiały one wrażenie kwestii drugorzędnych. Ze względu na to, że w projektowaniu geotechnicznym często to właśnie warunki SGU wpływają na wybór rozwiązań posadowienia, zdecydowano o podkreśleniu ich wagi i rozwinięciu wymagań stawianych ich weryfikacji. Jednym z elementów tych zmian jest wyszczególnienie kombinacji obciążeń, jakie należy stosować w przypadku sprawdzania warunków SGU.

\section{Stosowanie metod numerycznych}

Dotychczas Eurokod 7 dopuszczał, a w niektórych przypadkach wręcz zalecał stosowanie metod numerycznych. Brakowało w nim wytycznych dotyczących współczynników częściowych i weryfikacji SGN. Metody numeryczne, zwłaszcza MES, są obecnie powszechnie używane $\mathrm{w}$ projektowaniu konstrukcyjnym i geotechnicznym, co zdecydowano uwzględnić w nowej wersji normy. Dla stanu granicznego nośności przewiduje się sprawdzenie $\mathrm{z}$ dwoma zestawami współczynników częściowych:

- analizę dla charakterystycznych (lub najbardziej prawdopodobnych) wartości parametrów materiałowych z zastosowaniem współczynników częściowych do efektów oddziaływań (EFA - podobny do obecnego DA2*),

- analizę z zastosowaniem współczynników częściowych do parametrów geotechnicznych, redukujących ich wartości (MFA - podobny do obecnego DA3).

Ponadto zalecane jest użycie zaawansowanych modeli gruntu (nieliniowych, uwzględniających małe lub duże odkształcenia). Rozróżnia się również analizy sprawdzające warunki SGU oraz prognozujące zachowanie konstrukcji.

\section{Badania podłoża}

Choć prace nad drugą częścią nowego Eurokodu 7 dopiero trwają, już podjęto istotne decyzje na temat formy nowego dokumentu. Przede wszystkim ustalono, że powinna ona spełniać potrzeby projektantów, a nie wykonawców badań polowych i laboratoryjnych.

Część rozdziałów zostanie usunięta $\mathrm{z}$ odesłaniem do odpowiednich norm EN dotyczących badań podłoża. Pozostaną wymagania ogólne oraz postanowienia o wartościach wyprowadzonych. W chwili obecnej proponowane jest ustalenie minimalnych wymagań dla najprostszych konstrukcji oraz warunków topograficznych i geotechnicznych. Dla bardziej złożonych sytuacji byłyby podane typowe zalecenia dotyczące głębokości i rozstawów punktów badań, albo będą one traktowane jako ustalane w poszczególnych krajach odpowiednio do ich warunków geologicznych. Norma powinna zawierać postanowienia dotyczące budowli zaliczanych do pierwszej i drugiej kategorii geotechnicznej (GC1 i GC2). W odniesieniu do kategorii GC3 podane będą wymagania minimalne. Wybór metod, a także ich stosowanie i interpretacja wyników będą zadaniem eksperta-geotechnika.

Ponadto nowym pojęciem są „stopniowe” badania podłoża (ang. incremental ground investigation), dostosowujące zakres badań do faz dokumentacji. Zasadność takiego podejścia wynika $\mathrm{z}$ koncepcji zarządzania ryzykiem $\mathrm{i}$ choć jest ona $\mathrm{w}$ pełni uzasadniona, dotychczas nie stała się powszechną praktyką. 


\section{Konstrukcje geotechniczne}

Zalecenia dla konkretnych konstrukcji geotechnicznych będą stanowiły główny przedmiot trzeciej części nowego Eurokodu 7. Prace nad nimi dopiero podjęto. Najważniejszą zmianą jest uzupełnienie Eurokodu 7 o konstrukcje geotechniczne dotychczas nieobjęte normą, przede wszystkim posadowienie na podłożu wzmocnionym oraz stosowanie gruntów zbrojonych.

\section{Mechanika skał}

Obecnie Eurokod 7 (PN-EN 1997-1:2008) praktycznie nie uwzględnia projektowania geotechnicznego w przypadku występowania skał. Przedstawione w nim wymagania są lakoniczne, a czasem wręcz mylące. $Z$ tego względu rozszerzenie normy o zakres mechaniki skał stanowi jeden $\mathrm{z}$ celów obecnych zmian. $\mathrm{Z}$ uwagi jednak na niewielką liczbę specjalistów z tej dziedziny zaangażowanych $\mathrm{w}$ prace nad normą przedstawienie jasnych wskazówek przydatnych dla przeciętnego projektanta jest mało prawdopodobne.

\section{Dynamika}

Zarówno dotychczasowa norma PN-EN 1997:2004, jak i obecna wersja robocza prEN 1997-1:2017 nie poruszają wystarczająco tematyki oddziaływań dynamicznych. Podobnie jak w przypadku mechaniki skał, rozszerzenie tego elementu również stanowi jeden $\mathrm{z}$ ważnych kierunków wprowadzanych zmian. W praktyce jednak, z uwagi na swój ogólny charakter, Eurokody najprawdopodobniej nadal nie będą oferowały tak szczegółowej pomocy jak dotychczasowe polskie normy. $\mathrm{Z}$ uwagi na niewielką liczbę zaangażowanych specjalistów i ich specjalizację głównie w dziedzinie trzęsień ziemi, a nie drgań spowodowanych ruchem lub pracą maszyn, prace koncentrują się na kierunku sejsmicznym i częściowym dublowaniu zakresu normy PN- EN 1998-1:2005.

\section{SYSTEM ZARZĄDZANIA JAKOŚCIA}

Zaproponowany w prEN 1990:2017, a zaadaptowany na potrzeby prEN 1997:2017, system zarządzania jakością stanowi ważny element zapewnienia niezawodności konstrukcji przez przyjęcie określonych zasad w odniesieniu do procesu projektowania, wykonawstwa, a także eksploatacji. Najważniejszą modyfikacją wcześniejszych propozycji zmian, wprowadzoną na skutek protestu wielu krajów członkowskich CEN, jest przywrócenie koncepcji kategorii geotechnicznych jako elementu tego systemu. Zależność między nimi a pozostałymi elementami normy przedstawiono na rysunku. Zależność kategorii geotechnicznej od klas konsekwencji zniszczenia i złożoności warunków geotechnicznych przedstawiono w tabeli 6. Docelowo

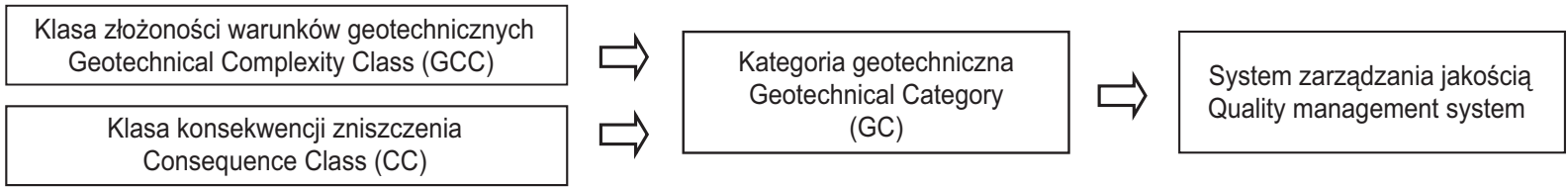

Rys. Schemat systemu zarządzania jakością - na podstawie prEN 1990:2017

Fig. Quality management system flowchart - based on prEN 1990:2017

Tabela 6. Kategorie geotechniczne - prEN 1990:2017

Table 6. Geotechnical categories - prEN 1990:2017

\begin{tabular}{|c|c|c|c|}
\hline \multirow{2}{*}{$\begin{array}{l}\text { Klasa konsekwencji } \\
\text { Consequence Class } \\
\text { (CC) }\end{array}$} & \multicolumn{3}{|c|}{ Klasa złożoności warunków geotechnicznych - Geotechnical Complexity Class (GCC) } \\
\hline & niższa / lower (GCC1) & normalna / normal (GCC2) & wyższa / higher (GCC3) \\
\hline Wysoka / Higher (CC3) & $\mathrm{GC} 2$ & GC3 & GC3 \\
\hline Normalna / Normal (CC2) & GC2 & GC2 & GC3 \\
\hline Niska / Lower (CC1) & GC1 & $\mathrm{GC} 2$ & $\mathrm{GC} 2$ \\
\hline
\end{tabular}


w zależności od przypisanej kategorii geotechnicznej dobierany będzie właściwy dla oczekiwanego poziomu niezawodności konstrukcji poziom:

- minimalnego zakresu rozpoznania podłoża gruntowego,

- minimalnej walidacji modeli obliczeniowych użytych w projektowaniu,

- minimalnego zakresu monitorowania,

- zakresu sprawdzenia projektu,

- wykonawstwa, nadzoru i inspekcji,

- minimalnych kwalifikacji i doświadczenia projektanta.

\section{PODSUMOWANIE}

Wprowadzenie Eurokodów budowlanych było ważnym wydarzeniem w normalizacji - zunifikowane wymagania projektowe są już powszechnie stosowane, znalazły też naśladownictwo poza Europą. Jak każde dzieło ludzkie okazały się niedoskonałe i są obecnie ulepszane.

W artykule przedstawiono tylko najważniejsze ze zmian zaproponowanych w projektach norm prEN 1990:2017 i prEN 1997-1:2017. Choć zmiany te stanowią ewolucje dotychczasowych wersji norm, będą miały istotne konsekwencje dla projektowania geotechnicznego. Wyróżniająca cechą zmian jest praktyczne wprowadzenie zasad kontroli niezawodności i zarządzania jakością.

Pomimo zwiększenia zakresu rodzajów konstrukcji i problemów geotechnicznych poruszonych w nowych normach, nadal nie będą one obejmowały wszystkich zagadnień oraz szczegółowych rozwiązań napotykanych $\mathrm{w}$ praktyce projektowej. Projektanci oraz osoby odpowiedzialne za badania podłoża nadal będą zmuszeni do polegania na swoim doświadczeniu oraz w dużym stopniu na dotychczasowej praktyce krajowej. Wprowadzenie nowej wersji Eurokodu 7 może mieć pozytywny wpływ na projektowanie geotechniczne w Polsce, ale nie rozwiąże wielu dotychczasowych problemów, z jakimi nadal muszą zmagać się projektanci, wykonawcy i inwestorzy.

\section{PIŚMIENNICTWO}

AS 2159 (2009). Australian standard. Piling. Design and installation.

Bond, A. (2017). Basis of geotechnical design. Presentation at SC7 Working Group meeting, Berlin.

CEN-CENELEC (2017). Internal Regulations. Part 3: Principles and rules for the structure and drafting of CEN and CENELEC documents (ISO/IEC Directives. Part 2: 2016, modified).

CEN/TC250 N1250 (2017). Policy Guidelines and Procedures. Version 6.

CEN/TC250/SC7 N1111 (2017). M515 SC7.PT2 Background document to N1110 'EN 1997-1. Final Draft.

CEN/TC250/SC7 N1112 (2017). M515 SC7.PT2 Replay to comments EN 1997-1. April draft.

Fenton, G. A., Naghibi, F., Dundas, D., Bathurst, R. J. i Griffiths, D. V. (2016). Reliability-based geotechnical design in 2014 Canadian Highway Bridge Design Code. Canadian Geotechnical Journal, 53, 236-251.

Kłosiński, B. (2017a). Kierunki zmian i rozwoju nowej wersji Eurokodu 7:2020. XXXII Ogólnopolskie Warsztaty Pracy projektanta i konsultanta (strony 167-182). Wisła.

Kłosiński, B. (2017b). Perspektywy zmian Eurokodu 7: Projektowanie geotechniczne. Inżynieria i Budownictwo, 3, 138-142.

Kłosiński, B. (2017c). Problemy sprawdzania stanów zniszczenia hydraulicznego według Eurokodu 7. Analizy i doświadczenia w geoinżynierii. W Jubileusz Prof. Gryczmańskiego (strony 209-219). Gliwice: Wydawnictwo Politechniki Śląskiej.

Ministerstwo Środowiska, (2007). Rozporządzenie Ministra Środowiska z dnia 20 kwietnia 2007 r. w sprawie warunków technicznych, jakim powinny odpowiadać budowle hydrotechniczne i ich usytuowanie. Dz.U. 2007 nr 8, poz. 579.

PN-EN 1990:2004. Eurocode0. Basis of structural design.

PN-EN 1997-1:2008. Eurokod 7. Projektowanie geotechniczne. Część 1: Zasady ogólne.

PN-EN 1998-1:2005. Eurokod 8. Projektowanie konstrukcji poddanych oddziaływaniom sejsmicznym. Część 1 : Reguły ogólne, oddziaływania sejsmiczne i reguły dla budynków.

PN-ISO 2394:2015. General principles on reliability for structures. 
Poulos, H.G. (2004). An Approach for Assessing Geotechnical Reduction Factors for Pile Design. Proceedings of the 9th Australia New Zeland Conference on Geomechanics, Tom 1 (strony 109-115). New Zeland, Auckland.

prEN 1990:2017. Eurocode: Basis of structural and geotechnical design.
prEN 1997-1:2017. Eurocode 7. Part 1: General rules. Final Draft for informal enquiry.

S6-14 (2014). Canadian Highway Bridge Design Code, CSA. Simpson, B. (2017). Eurocode 7 and Robustness. GeoRisk 2017 Conference. Denver.

\title{
NEW GENERATION OF EUROCODES - CHANGES IN GEOTECHNICAL DESIGN
}

\begin{abstract}
After a few years from official implementation of Eurocodes, as harmonized European standards, replacing former Polish standard, and over ten years from their first publication in current form, the works on the second generation of Eurocodes have begun. The paper presents the state of standardization works in regard to Eurocode 7, focusing on its part 1 covering general rules of geotechnical design. Some controversial matters as well as internal CEN bylaws and guidelines are discussed to give a background behind some of the introduced changes. To fully comprehend the difficulties of this standardization process, the context of the changes has to be accounted for.
\end{abstract}

Key words: Eurocode 7, geotechnical design, standardization 